\title{
Revisiting China's Sponge City Planning Approach: Lessons From a Case Study on Qinhuai District, Nanjing
}

\author{
Shiyang Chen ${ }^{1,2 *}$, Frans H. M. van de Ven ${ }^{1,2 *}$, Chris Zevenbergen ${ }^{3,4}$, Simon Verbeeck ${ }^{5}$, \\ Qinghua $\mathrm{Ye}^{2,3}$, Weijun Zhang ${ }^{6}$ and Liang Wei ${ }^{7}$
}

${ }^{1}$ Department of Water Management, Faculty of Civil Engineering and Geosciences, Delft University of Technology, Delft, Netherlands, ${ }^{2}$ Deltares, Delft, Netherlands, ${ }^{3}$ Department of Hydraulic Engineering, Faculty of Civil Engineering and Geosciences, Delft University of Technology, Delft, Netherlands, ${ }^{4} \mathrm{IHE}$ Delft Institute for Water Education, Delft, Netherlands, ${ }^{5}$ LOLA Landscape Architects, Rotterdam, Netherlands, ${ }^{6}$ Ewaters, Shanghai, China, ${ }^{7}$ Achterboschzantman International, Leeuwarden, Netherlands

\section{OPEN ACCESS}

Edited by: Ahmed El Nemr, National Institute of Oceanography and Fisheries (NIOF), Egypt

Reviewed by:

James Andrew Griffiths, National Institute of Water and Atmospheric Research (NIWA), New Zealand Jiahong Liu, China Institute of Water Resources and Hydropower Research, China

*Correspondence: Shiyang Chen shiyang.chen07@gmail.com Frans H. M. van de Ven f.h.m.vandeven@tudelft.nl

Specialty section:

This article was submitted to Water and Wastewater Management, a section of the journal Frontiers in Environmental Science

Received: 27 July 2021 Accepted: 13 September 2021 Published: 28 September 2021

Citation:

Chen S, van de Ven FHM, Zevenbergen $C$, Verbeeck $S$, Ye $Q$, Zhang $W$ and Wei $L$ (2021) Revisiting

China's Sponge City Planning Approach: Lessons From a Case Study on Qinhuai District, Nanjing.

Front. Environ. Sci. 9:748231. doi: 10.3389/fenvs.2021.748231
Integrating sustainable urban water management into the urban planning process is essential for developing water-resilient cities. To this end, the central government of the People's Republic of China initiated the "Sponge City" programme. However, challenges and gaps exist in current urban planning practice. The operationalizable planning approach to realise the multiple objectives of Sponge City is missing in the existing guidelines. Using a local example of Sponge City planning in Nanjing City as a case study, this paper outlines the current Sponge City approach from the perspectives of planning content and planning process. A qualitative comparative analysis between Nanjing's Sponge City planning and Auckland Water Sensitive Design, as well as an evaluation of the Sponge City approach through the lens of Dutch urban water management, identified key missing elements that would enhance the current Sponge City planning approach. Examples include targets for pluvial flood protection, a strategy for planning interventions, and tools for interdisciplinary cooperation in the planning process. This enhanced approach was successfully applied in the Sponge City planning for Qinhuai District, Nanjing City. Nevertheless, challenges on data availability and the decisionmakers' mindsets called for more efforts on the interface of research and policy development for upscaling the Sponge City approach.

Keywords: Sponge City, water management, urban planning, comprehensive approach, co-design

\section{INTRODUCTION}

In order to comply with the concept of sustainability, many countries issued policies to support urban development with a minimum impact on the environment. The European Green Deal provides a roadmap for making the EU's economy sustainable by turning climate and environmental challenges into opportunities across all policy areas and making the transition just and inclusive for all (European Commission, 2019). Similarly, the ecological civilization (or eco-civilization) endorsed by the Chinese government calls for prioritizing resource conservation, ecosystem protection, and rehabilitation through a green, circular, and low-carbon development approach (State Council, 2015). 
TABLE 1 | Challenges in planning content and process of current Sponge City.

\begin{tabular}{|c|c|c|c|}
\hline Category & Challenges & References & Implication \\
\hline \multirow[t]{4}{*}{$\begin{array}{l}\text { Planning } \\
\text { content }\end{array}$} & $\begin{array}{l}\text { "[...] a national standard is critically needed for planning and organising } \\
\text { SCD [Sponge City development] at the city or basin level to bridge the } \\
\text { onsite engineering design of individual LID practices and the functional } \\
\text { goals of sponge cities. The importance and necessity of such a } \\
\text { holistic systematic approach is further justified by the complexity and } \\
\text { interlinkage of the multiple urban water issues [...]projects under SCD } \\
\text { should function not only to tackle flooding and other water issues but } \\
\text { also to take the opportunity to improve urban liveability and } \\
\text { development sustainability." }\end{array}$ & Ma et al. (2020) & $\begin{array}{l}\text { The need of holistic thinking of urban water systems with } \\
\text { multiple objectives and co-benefits }\end{array}$ \\
\hline & $\begin{array}{l}\text { "the GB50014-2006 code [Code for design of outdoor wastewater } \\
\text { engineering] of practice does not indicate how drainage design should be } \\
\text { undertaken in older towns or districts, or indicate how current practices } \\
\text { should be integrated with new, more sustainable drainage } \\
\text { practice." }\end{array}$ & $\begin{array}{l}\text { Chan et al. } \\
\text { (2018) }\end{array}$ & \\
\hline & $\begin{array}{l}\text { "They [guidelines] are, by large, merely the translation and combination of } \\
\text { similar the guidelines widely used in the US and do not consider } \\
\text { variations in regional and local conditions such as soil, climate and } \\
\text { topography variances. Lack of design standards and codes has limited the } \\
\text { ability of local communities to implement sponge city projects based on } \\
\text { local conditions." }\end{array}$ & Li et al. (2017) & \\
\hline & $\begin{array}{l}\text { "Need of integrated urban water system theory.[...]Although the } \\
\text { construction guideline of Sponge City was proposed, the widely-used } \\
\text { control rate of annual average runoff amount only focused on the storage } \\
\text { and infiltration measures of source controls with deficient capacities." }\end{array}$ & Xia et al. (2017) & \\
\hline \multirow[t]{4}{*}{$\begin{array}{l}\text { Planning } \\
\text { process }\end{array}$} & $\begin{array}{l}\text { "the competing priorities of stakeholders and their reluctance to } \\
\text { make trade-offs, which obstruct future investment in the SCP [Sponge } \\
\text { City Program]" }\end{array}$ & Qi et al. (2020) & $\begin{array}{l}\text { The need of stimulating efficient and effective stakeholder } \\
\text { engagement (co-design) process }\end{array}$ \\
\hline & $\begin{array}{l}\text { "[...] the inter-agency cooperation and working across functions } \\
\text { has not always been easy in China due to the difficulty of working across } \\
\text { divisions, agencies, and political boundaries with diverse groups and } \\
\text { diverse interests." }\end{array}$ & Li et al. (2017) & \\
\hline & $\begin{array}{l}\text { "[...] sponge city systems are mostly built above ground and scattered in } \\
\text { large regions; some located in private land interfering with public life. } \\
\text { Therefore, public opinion and acceptance of sponge city } \\
\text { construction can easily hinder its success." }\end{array}$ & Li et al. (2017) & \\
\hline & $\begin{array}{l}\text { "Complexity of hydrological models impedes the multi-disciplinary } \\
\text { collaboration." }\end{array}$ & Cai, (2016) & \\
\hline
\end{tabular}

Water is increasingly recognized by urban planners as an essential steering element to realize urban sustainability goals (Hooimeijer, 2014; Stead, 2014; Hurlimann and Wilson, 2018). The international trend of urban water management is to develop "water sensitive cities" (Brown et al., 2009). To this end, new planning and design concepts emerged, such as Low Impact Development, Sustainable Urban Drainage Systems, and Water Sensitive Urban Design. These planning and design concepts embrace interlinking nature-based solutions (NBS) with grey infrastructures to increase urban resilience via peak flow reduction, water quality improvement, and by developing new ecosystem services within the limitedly available urban space. One of the crucial challenges hindering the implementation of such concepts is how to value and design hybridized blue-green-gray systems with a variety of stakeholders (Kumar et al., 2020).

The rapid increase of impervious surfaces and removal of natural water storage such as natural wetlands and lakes due to urbanization has increased the occurrence of urban flooding in China (Wang et al., 2012). According to an investigation carried out by the Ministry of Housing and Urban-Rural Development
(MHURD) in 2010, 137 of 351 Chinese cities suffered more than three flooding events from 2008 to 2010 (Che and Zhang, 2019). In addition, more than 400 cities are short of water supply; 110 cities face severe water shortage situations (Li et al., 2016). Moreover, polluted water discharged into surface water and groundwater has severely impacted public health and the local ecology (He and Xing, 2006; Sun et al., 2016). Faced with issues of flooding, drought, aquatic habitat degradation, and groundwater depletion, China needed an integrated and comprehensive solution involving not one single department but multiple departments (Yu et al., 2015). For these reasons, the Sponge City Programme was initiated in 2014 by the Chinese central government (MHURD, 2014).

Since then, the Sponge City concept has been tested and become increasingly developed. According to the definition given in the evaluation standard of 2018, the concept has expanded on 2014s guidelines to become an integrated urban water management strategy incorporated in urban planning and design. The Sponge City concept now including objectives of water ecology, water resource, water environment, water safety, and water culture (MHURD, 2018). 


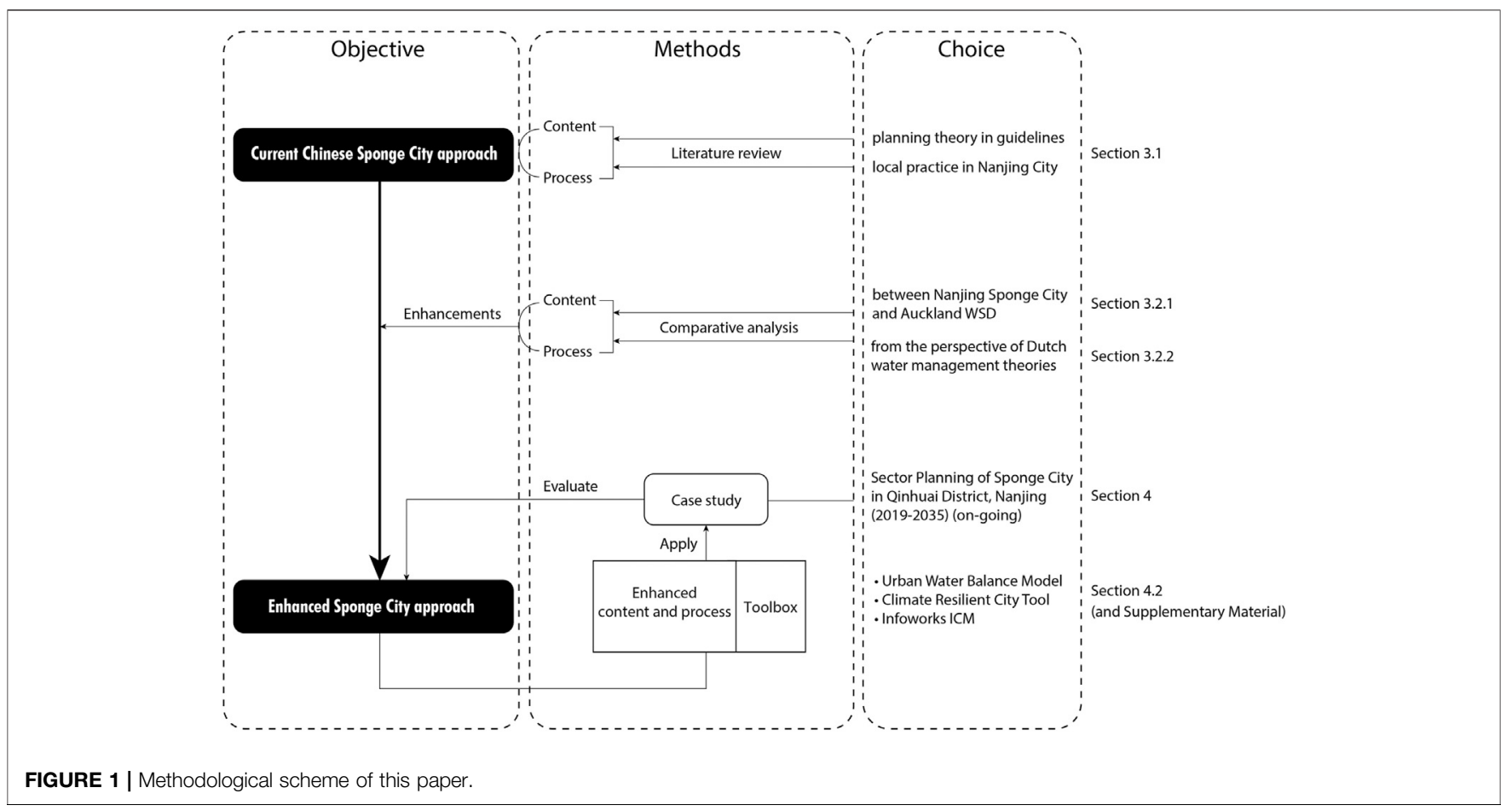

However, scholars reported difficulties regarding its implementation in practice. Practitioners, such as water planners/managers/engineers, struggle with both contents of the Sponge City concept and the organization of an effective and efficient planning process. Key challenges in Sponge City planning fall into two dimensions, i.e., planning content-what is being addressed-and planning process-how these issues are being addressed (see Table 1). The lack of an operationalizable and justifiable approach considering both holistic urban water systems and stakeholder engagement is a crucial factor impeding the local implementation of the Sponge City concept.

This article aims to evaluate the current Sponge City planning practice in Nanjing, identify challenges and gaps, in which an enhanced planning approach can be formulated, and to demonstrate the enhanced planning applicability using Qinhuai District in Nanjing as a case study.

\section{METHODOLOGY}

\section{Enhancing the Planning Approach}

In order to enhance the current Sponge City planning practice in Nanjing and reveal challenges and gaps in the application of this enhanced approach, we first present the latest developments in existing Sponge City planning, based on studies of both national governmental policy documents and documents on local policy implementation in Nanjing. Current Sponge City local implementation is analysed in two dimensions, i.e., planning content-what is being addressed-and planning process-how these issues are being addressed. To identify options to improve this current
Sponge City planning approach, we use qualitative methods, including literature review and comparative analysis, as illustrated in Figure 1.

The differences between China's Sponge City and other approaches to urban water management can be found by comparing their overarching guiding principles and concepts (see Supplementary Material SA). Since Water Sensitive Urban Design (WSD) and Sponge City share the strategy of incorporating stormwater management in the urban planning process, the guidelines of Nanjing Sponge City planning are compared with those of Auckland's Water Sensitive Design. WSD also includes approaches like Low Impact Development and Sustainable Urban Drainage Systems and is considered comprehensive. Both the Sponge City approach and the WSD approach are typically customized for the local conditions in a specific city. That is why a comparison at the local level is appropriate. In addition, to test the robustness of the underlying principles in the Sponge City planning approach, the approach is evaluated through the lens of the principles in water management practices of the Netherlands. The Dutch principles are used as evaluation criteria since the well-developed Dutch water management practices may provide inspiring experiences to other countries with similar situations.

Differences between the approaches-in terms of both planning content and planning process-allowed us to reflect on the Sponge City approach and identify potential improvements in the planning content and the process. Based on the results, an adapted Sponge City planning approach is proposed and, as a hypothesis, is considered to be an enhanced version. This enhanced version of Sponge City planning approach is evaluated by its application in an ongoing 


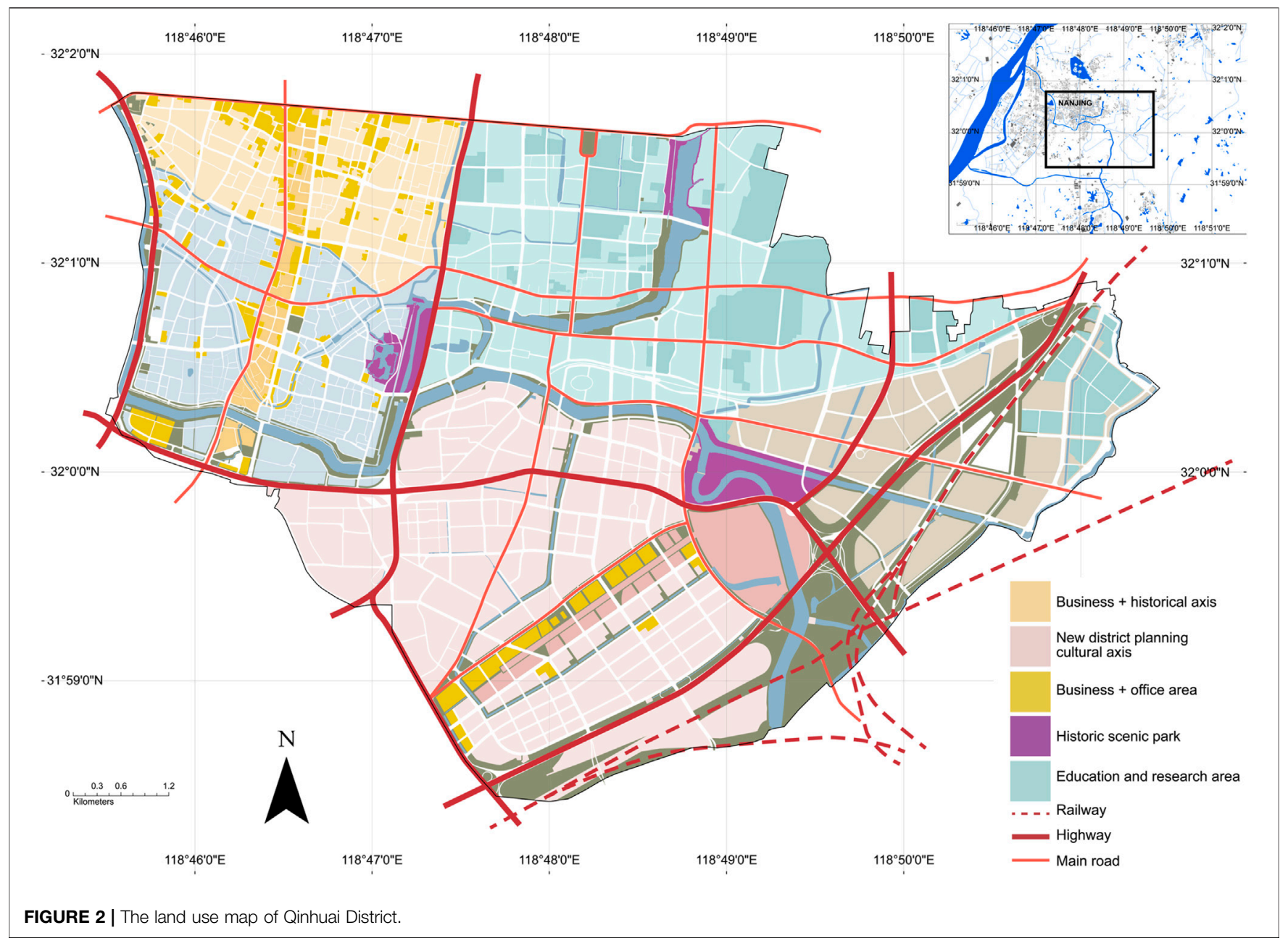

Sponge City planning project of Qinhuai District, Nanjing City.

\section{Case Study Description}

Development and application of the enhanced Sponge City approach was part of a project to implement the national Sponge City policy at the local level of Nanjing City. The objective was to deliver a Sponge City plan for Qinhuai District, including sponge measures to mitigate pluvial flooding and improve surface water quality while obtaining co-benefits such as mitigation of the urban heat island effect, strengthening water culture, etc. The enhanced Sponge City planning approach was applied (including spatial analysis, sponge size calculation, hydraulic modelling, suggested sponge measures, etc.), and its results were incorporated in the project outcomes. The case study is used to demonstrate how the enhanced approach can be applied in practice with an evaluation to determine the added value of the newly created measures.

Several tools were applied to provide insights into both the potentials and the challenges of the proposed sponge measures. Tools used for this research include the Urban Water Balance Model (Brolsma and Vergroesen, 2020), InfoWorks ICM (Costa et al., 2021), and Climate City Resilient Tool (CRCT) (van de Ven et al., 2016; McEvoy et al., 2018; McEvoy, 2019).

\section{Site Description}

Nanjing City is situated at the Yangtze River Delta, which has a humid subtropical climate influenced by the East Asian monsoon (Mao et al., 2012). Between 1949 and 1978, in need of land, the government filled canals and ponds without realizing their hydrological, historical, ecological, landscape, and other values (Liu and Han, 2014). Consequently, intense precipitation in the rainy season with other factors such as urban landcover change, low topography, etc., has resulted in frequent flooding hazards in recent decades.

Qinhuai District is located at the heart of Nanjing City with a total area of $49 \mathrm{~km}^{2}$, south of the city's downtown, with the old royal palace clustered in the northwest and old canal networks interweaved in the urban landscape (see Figure 2).

Qinhuai District contains 19\% green spaces and 6.8\% water surfaces. These blue and green spaces are scattered and have not yet been planned to systematically contribute to eco-system protection, flood defence, recreation, and other co-benefits. Stormwater runoff in Qinhuai District is conveyed by a separate system of pipes and local canals, pumped into the Qinhuai River, and further discharged to the Yangtze River. The current strategy for pluvial flood protection is "discharge", 
without consideration of "retain" and "store" in urban planning. Moreover, poor water quality in the canal systems not only endangers the aquatic ecosystem but also hinders local heritage protection. Sponge City planning can be a trigger to smooth the confrontation between historical cultural heritage and urban development, especially in the north-western area of the district.

\section{COMPARATIVE ANALYSIS OF THE CURRENT SPONGE CITY PLANNING APPROACH}

\section{Sponge City Planning Approaches and Its Local Application in Nanjing}

After the first official debut at the Central Urbanization Conference in 2013, the Sponge City concept was formulated and supported by a series of documents from the central government. MHURD released the first technical guideline of Sponge City construction (MHURD, 2014), which outlines the technical framework of Sponge City construction. The approach integrates the Sponge City concept in the urban planning processes, including land development, greenery planning, water system planning, transport planning, etc., The first version of governmental documents formulated performance indicators on six aspects, i.e., water ecology, water environment, water resources, water safety, institutional system building and implementation, demonstration effects (MHURD, 2015). The request of making local Sponge City planning, published by MHURD in March 2016, sets general principles of downscaling Sponge City indicators to city level (MHURD, 2016). In 2018 the official national standard was released for evaluating sponge effects (MHURD, 2018).

It can be concluded from those guiding documents that Sponge City seeks a comprehensive approach to solve urban water related issues; Stormwater is to be managed by at-source measures, en route conveyance, and end-of-pipe measures. Water retention is required as part of the ecological indicators. The size of this "sponge" is determined by an indicator called VCRa (Volume Capture Ratio of annual rainfall).

Driven by the central government's policy, the Sponge City concept, and the planning approach cascaded down to local levels, with more detailed local interpretations and planning procedures. Such local applications are, e.g., found in the Sponge City plans of multiple administrative levels in Nanjing City. Our analysis of these plans gave detailed insights into the local implementation/interpretation process (NPNRB 2018a; 2018b; Wei, personal communication, December 4, 2019). The Nanjing Sponge City planning content and process are illustrated in Figure 3 and Figure 4, respectively.

As shown in Figure 3, Nanjing's Sponge City approach covers five topics, each of which has different sub-topics in the next ring. The main topics are water safety, water ecology, water environment, and water resources. For areas with significant water-related historical or social values, water culture is also considered in their sponge planning. Potential problem assessment approaches are listed in the ring next to sub-topics. The outermost ring includes objectives for tackling issues under each topic. Plans at the city and district levels all cover this content.

The framework in Figure 4 describes three components of the planning process, i.e., planning, project, and responsible authorities. Three coloured frames represent different types of planning, i.e., master planning, detailed spatial planning, as well as Sponge City and other sectoral planning. The blue line and the green line represent the connection of different planning procedures concerning water and green systems, respectively. Coloured bullets in the Project component of Figure 4 stand for different authorities, taking specific responsibilities in different project phases.

Analysis of this process framework is conducted from three perspectives:

1. The relationship between sponge city planning and other planning.

Sponge City planning is interwoven with other sector planning. Sponge City plans to integrate information, objectives, and implementation plans from other plans, such as urban spatial planning, water system planning, flood control planning, green system planning, ecological protection planning, etc., Vice-versa, Sponge City plans provide policy suggestions to these plans.

2. Downscaling Sponge City requirements.

Sponge City performance requirements are downscaled from larger administrative regions to smaller subzones. Nanjing's Sponge City plan has four subzone scales related to the normal spatial scales of city-district-neighbourhood, i.e., city, city divisions, drainage basins, and control units. Targets for Sponge City indicators are downscaled from city to district, and from there to drainage basins and control units. This ensures that objectives are achieved as the performance indicators of lower-level units are aggregated to upper-level units. Obligatory indicators such as VCRa and recommended indicators are assigned to each control unit and must be respected by land and project developers. Compensation of a deficit in one subzone by a surplus in another subzone is not allowed.

3. Involved authorities.

Many administrative authorities play an active role in guiding and assessing Nanjing's Sponge City planning. For example, Sponge Office (in pink), together with Natural Resource (in yellow) and Planning Bureau or Transport Bureau (in purple), is responsible for checking whether the (preliminary) design of a project fulfils Sponge City requirements before the construction permit is issued by Natural Resource and Planning Bureau (NPNRB, 2018b; 2018a). Intensive communication and information exchange is needed amongst different Bureaus, making the Sponge City planning process new and complex.

\section{Comparative Analysis}

\section{Auckland's Water Sensitive Design (WSD)}

To compare the Sponge City approach used in Nanjing to the WSD approach as applied in Auckland, several sources, especially guidelines, were studied (Healy et al., 2010; Lewis et al., 2015; Auckland Council, 2016; Cunningham et al., 2017; NPNRB, 2018b). Sponge City and WSD share many common elements 


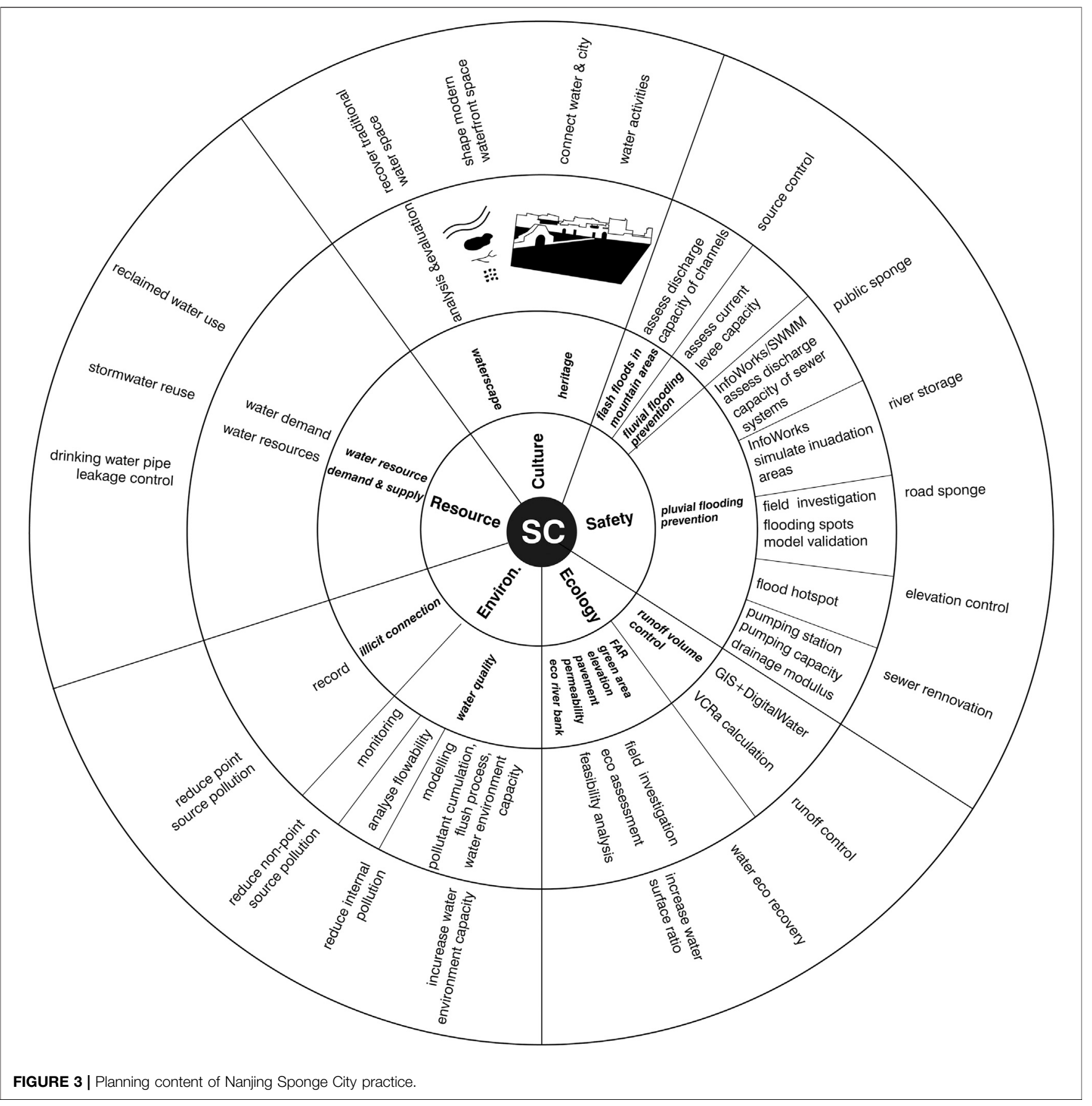

due to their similar philosophy. For example, both integrate the water and land development planning; However, the differences in guiding policies (demonstrated in Supplementary Material SB) lead to substantial differences in both contents and the structure of the planning process.

Content:

1. The objectives of Sponge City are indicator-oriented, setting standards or specific requirements. In contrast, WSD describes a clear vision, allows for flexibility, and leaves setting standards for indicators to the local stakeholders, depending on local conditions.

2. Unlike in Auckland's WSD, a comprehensive assessment of the local water system-as part of larger water and urban system-is missing in current Sponge City planning documents of Nanjing. For example, groundwater assessment and socio-cultural aspects are missing in both guidelines and plans of Nanjing Sponge City.

3. Principles outlined in WSD are explicit and clear, while vagueness in Sponge City guiding principles challenge its 

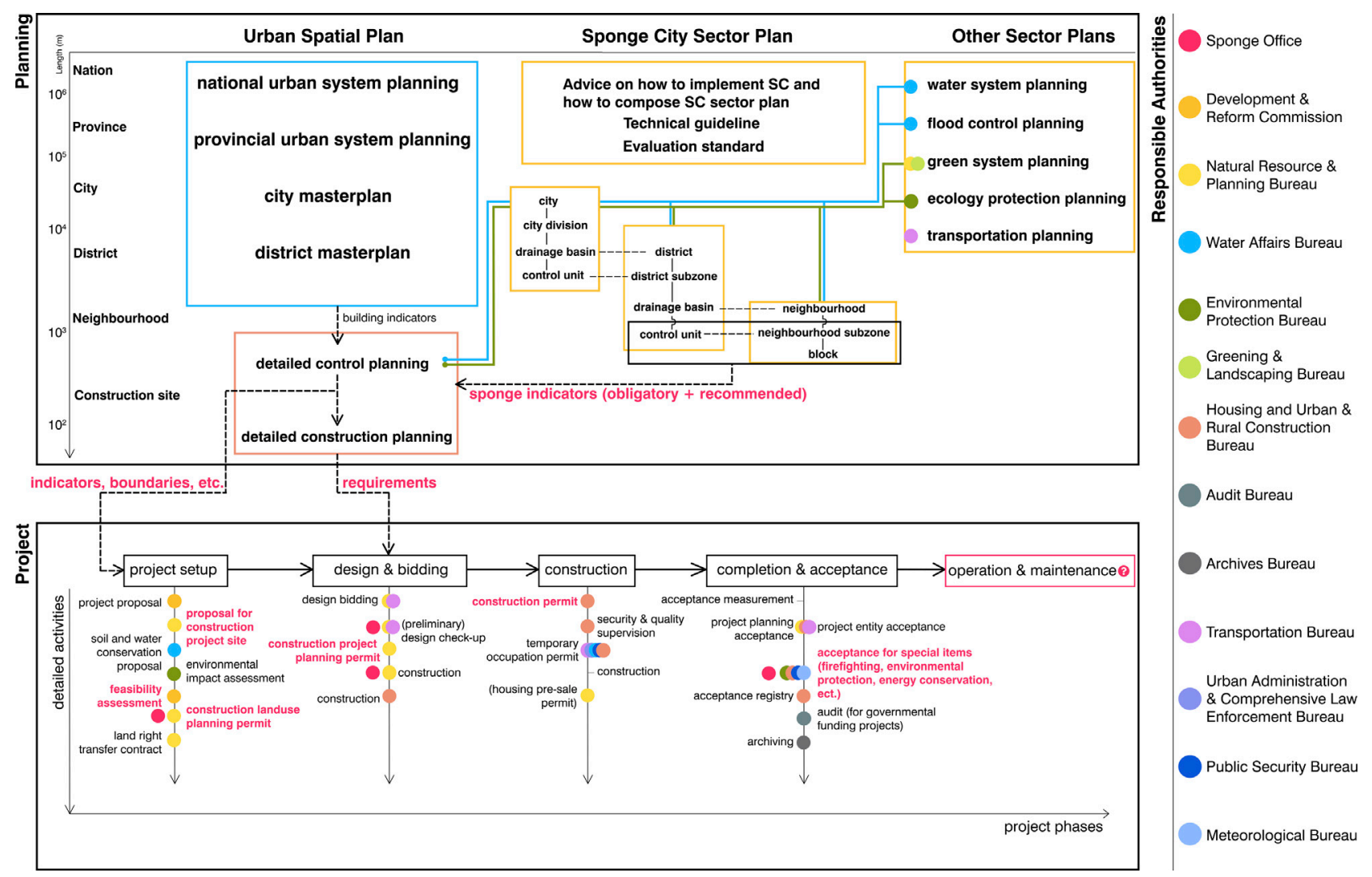

FIGURE 4 | Planning process of Nanjing Sponge City practice.

implementation; for example, the need to address stormwater close to its source is not mentioned.

4. WSD guidelines include an analysis of landscape and natural character values, as well as an analysis of past and expected future land development patterns. In contrast, spatial analysis in Sponge City planning mainly focuses on water and ecology.

5. In the Sponge City approach, the size of sponge measures is determined by the VCRa, an ecology-based indicator, similar to the Water Quality Volume in WSD. The VCRa, however, is not an indicator for designing sponge measures against pluvial flooding (Wang et al., 2015; Lin et al., 2019). No approach or calculation method is provided to design the sponge for pluvial flood protection. On the contrary, Auckland's WSD guidance documents distinguish measures for different spatial scales and different types of storms, which can be designed through standardized modelling and size calculation methods.

\section{Process:}

1. WSD is an inter-disciplinary design approach, whereas no specified inter-disciplinary collaboration mechanism is outlined in Sponge City approach.

2. WSD values the early engagement of local official actors and experts, which is not foreseen in the Sponge City approach.

3. WSD promotes the collaboration of stakeholders with regulators in the planning processes; while in the Sponge
City approach, consultation of local inhabitants is not required, nor any co-creation/collaborative design of plans.

4. WSD and Sponge City both incorporate their requirements into the land development approval process; WSD illustrates the design procedure with regulatory checks, while Sponge City guidelines explicitly specify the roles of authorities in regulatory checks.

5. WSD provides rich information on the operation and maintenance of various commonly-used stormwater devices, including consideration of operating conditions, costs, and responsibilities. Operation and maintenance advice on sponge measures are given in Nanjing Sponge City guideline, but the responsibility of maintenance is not defined nor recommended to consider in planning.

\section{Dutch Water Management Principles}

Dutch water management experiences are insightful to other countries facing flooding, drought, and water quality issues. Dutch central government is embedding the following principles in its recent national water policy (Ministry of Infrastructure and Environment Affairs and Ministry of Economic, 2009):

\section{- Comprehensive water management}

By considering the various tasks relating to water quantity (flood risk management and pluvial flooding), water quality, 


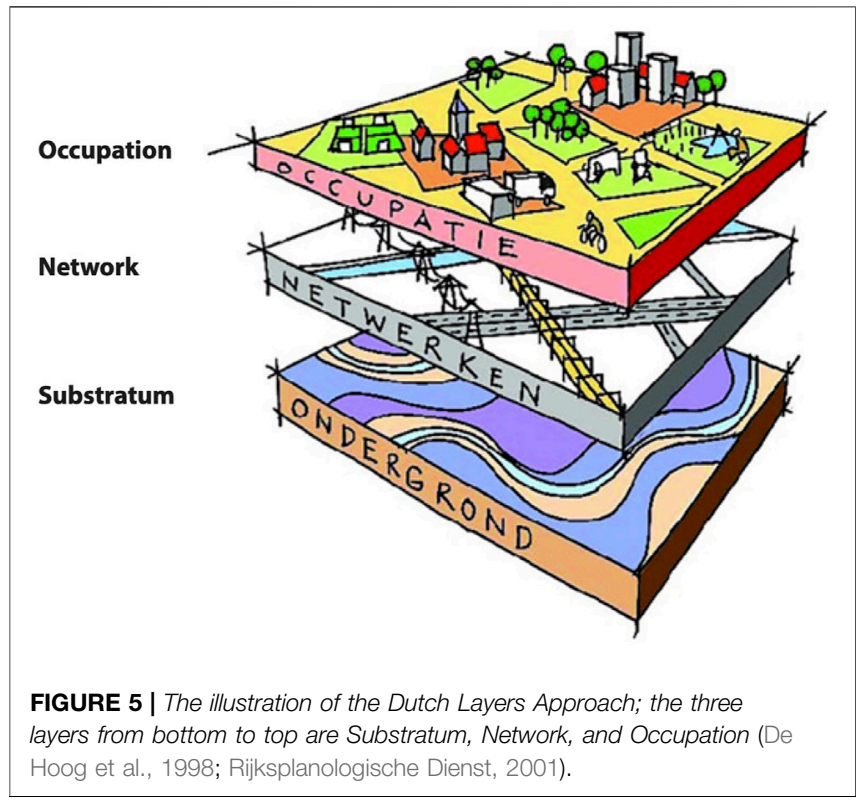

and the use of fresh water under wet and dry circumstances in a coherent way, a comprehensive approach is achieved.

- Prevent shifting (or Never Shift Problems in Dutch)

"Prevent shifting" is the centuries-old cornerstone of Dutch water management, which refers to preventing water quantity and quality problems being shifted in terms of space and time.

- Connecting space and water (including Layers Approach and Three Point Approach)

By connecting water planning with spatial planning, it is often possible to improve water management while at the same time reinforcing the economy and the residents' living environment at lower costs. Before implementing measures, the activities are first coordinated with the other relevant spatial tasks and developments in an area; several approaches and guiding models are developed to support this integration, including the Layers Approach (see Figure 5) to spatial planning and the Three Points Approach (see Figure 6) to flood risk reduction.

The Layers Approach (De Hoog et al., 1998; Rijksplanologische Dienst, 2001) distinguishes three layers of spatial planning tasks: substratum, networks, and occupation. Interventions in the occupation layer and the network layer are to be tuned to the properties of the subsurface and are to fit the water network, as well as other networks and objects in the occupation layer. The Three Points Approach is a method to help planning and designing flood risk reduction facilities (Fratini et al., 2012). Point 1 in Figure 6 represents the design of facilities protecting up to the level of the design return period. Point 2 represents a situation where this level is exceeded, and the protection system fails. Spatial planning aims at minimizing the damage of that failing system by strengthening its coping and recovery capacity (de Graaf et al., 2007). Point 3 represents the everyday situation. Instead of being a hindrance, drainage and protection facilities ought to provide added value and services to society every day.

- Embed technical solutions in good governance
The OECD published principles on water governance, covering 12 different aspects of governance (OECD, 2015). A more practical principle for evaluating the governance of interventions, however, is the PRIMO-chain approach (Adviesunit Resultaatgericht Beleid, Ministerie van Verkeer en Waterstaat, 1997): Policyi-Regulations and Legislation-Implementation capacity, execution capacity-Maintenance, monitoring and performance evaluation-Organisation and financing. If one of these elements is not in place, any intervention is doomed to fail.

These points allow for a comparison with the Sponge City approach (see Supplementary Material SC). Identified gaps in the current Sponge City planning approach are listed below.

Content:

1. Five water topics in Sponge City approach are treated separately, without addressing the synergies amongst them, which hinders the comprehensive management of the urban water system. Key water system components missing in the planning of sponge measures are groundwater management, pluvial flooding prevention, and drought mitigation.

2. There is a lack of sponge sizing method(s) to implement the principle Never Shift Problems in current Sponge City guidelines concerning pluvial flooding prevention.

3. The design method for additional resilience to future changes (Point 2 in Figure 6) is missing in Nanjing Sponge City planning. Moreover, everyday values (Point 3 in Figure 6), such as aesthetics, recreation values, etc., are not considered in current Sponge City planning.

Process:

1. Insufficient coordination between water and spatial planning experts while planning sponge measures.

2. Lack of involvement/engagement of various stakeholders to plan added values.

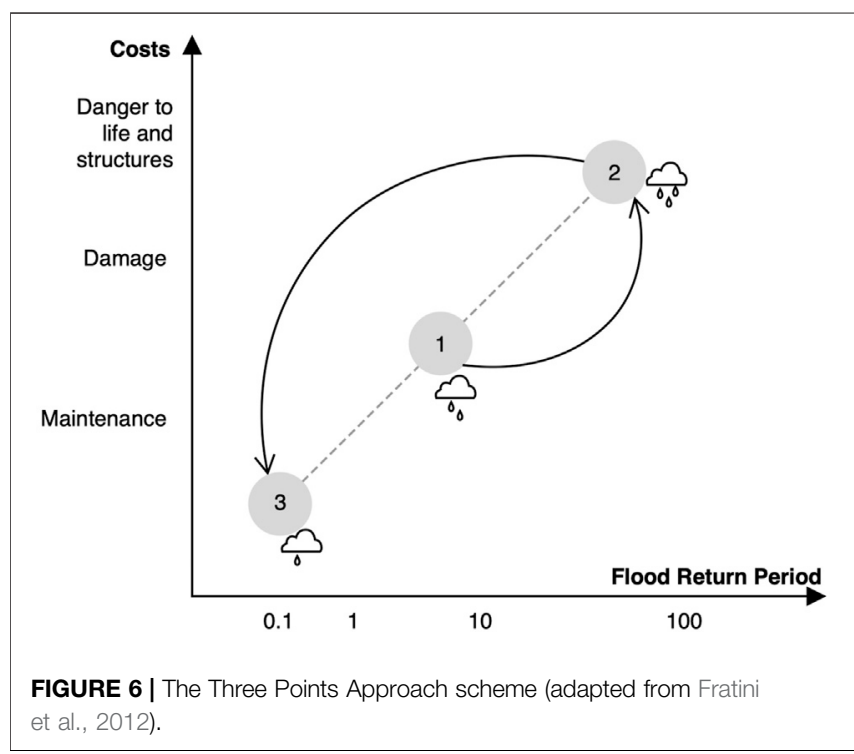



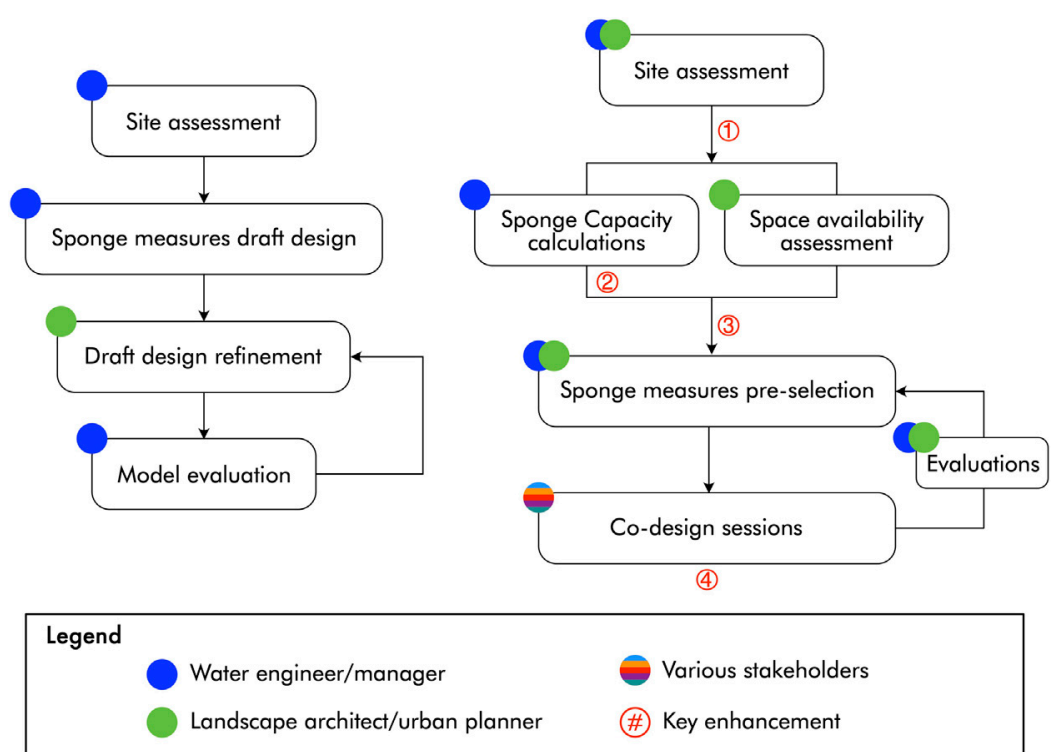

Various stakeholders

\# Key enhancement

FIGURE 7 | Current (left, Chen, 2020) and proposed (right) sponge measures planning process.

3. Critical issues in perusing good governance include: 1). Performance evaluation: Whether proposed sponge interventions meet the regulations and standards is hardly evaluated; 2). Policy and regulations on groundwater management are not yet available; 3). Responsibility for maintenance remains unclear.

\section{An Enhanced Version of Sponge City Planning Approach}

Comparative analysis in the previous sections shed light on potential improvements of the current Sponge City planning approach. Many differences were found that can enhance the current approach. Key enhancements on both content and process are:

1. Elaborate the guiding principles based on local conditions.

2. Take a comprehensive water management approach; build on the local conditions; include pluvial flood prevention, drought mitigation, groundwater, and water quality management.

3. Create added values.

4. Co-design the plan, involving relevant experts and stakeholders.

Based on the ideas above, an enhanced approach for a new planning process was outlined, as represented in Figure 7.

As a first step, water engineers/managers and landscape architects/urban planners perform site assessments, based which they can jointly refine and customize guiding principles. Secondly, water engineers assess the flood and drought risks and calculate the required storage capacity; in parallel, landscape architects or urban planners analyse available urban space for potential interventions. Thirdly, a pre-selection stage is introduced to jointly shorten the long list of potential sponge measures considering local conditions.
Fourthly, a participatory co-design workshop is organized for triggering discussion of sponge measure arrangement amongst relevant experts and stakeholders, e.g., urban designers, water engineers, civil engineers, local inhabitants, experts, governmental authorities, etc. During the workshop, participants are to be invited to share knowledge, expectations, preferences, etc., and make contributions to sponge measures selection and arrangement (van de Ven et al., 2016). Such co-design workshops are meant to produce one or more comprehensive conceptual intervention plans. This conceptual phase of planning is a timely opportunity for balancing interests and making choices (McEvoy et al., 2019). Finally, water engineers and urban designers collaborate in developing the conceptual Sponge City plan to a detailed design. Critical aspects such as environmental impact, cost-benefit analysis, etc., can thereby be evaluated, which might require involvement from other disciplines. Final decisions are based on this evaluation of expected impacts and effectiveness.

\section{APPLICATION OF THE ENHANCED APPROACH}

The enhanced approach was applied as far as possible in the Sponge City planning project for Qinhuai District. Limitations due to data availability, Covid-pandemic restrictions, and formal process requirements hindered a full use of the recommended approach. Nevertheless many new insights were gained.

\section{Issues According to the Current Sponge City Approach}

After spatial analysis, indicator assessment, and hydraulic modelling of the current situation, key issues regarding the 
TABLE 2 | Key issues and relevant indicators in Qinhuai District regarding the five Sponge City topics NPNRB (2018b); Wei, personal communication, December 4, 2019).

\begin{tabular}{|c|c|c|}
\hline Topic & Key issues & $\begin{array}{l}\text { Standards in Sponge City } \\
\text { planning of Qinhuai } \\
\text { District (targets by 2030) }\end{array}$ \\
\hline Water safety & $\begin{array}{l}\text { - Flood events occur once every } 8 \text { years on average due to heavy rainfall in large areas of } \\
\text { the district } \\
\text { - Increasing imperviousness causes more runoff volume and higher runoff rate } \\
\text { - Sewers were designed for return period of } 0.5-1 \text { year } \\
\text { - Blue and green areas are shrinking due to urbanization, which weaken the storage } \\
\text { capacity }\end{array}$ & $\begin{array}{l}\text { - Design return period } 50 \text { years for pluvial flood } \\
\text { prevention and control } \\
\text { - Design return period } 200 \text { years for fluvial flood } \\
\text { prevention and control } \\
\text { - Design return period } 3-5 \text { years for sewer systems } \\
\text { - Required storage capacity according to VCRa: } \\
25.6 \mathrm{~mm}\end{array}$ \\
\hline Water ecology & $\begin{array}{l}\text { - Average VCRa is } 38 \% \\
\text { - 'Hard' banks account for } 64 \% \text { of total length }\end{array}$ & $\begin{array}{l}\text { - VCRa: } 75 \% \text { for } 80 \% \text { of urban the built areas } \\
\text { - Ecological embankment ratio: } 80 \% \text { for new built areas }\end{array}$ \\
\hline $\begin{array}{l}\text { Water } \\
\text { environment }\end{array}$ & $\begin{array}{l}\text { - Water quality was tested as Class V in six out of seven cross-sections of Qinhuai canals } \\
\text { during 2015-2019. Class V is the poorest water quality category } \\
\text { - Water quality of groundwater at two test wells both indicates Class V quality during } \\
2015-2019 \\
\text { - Non-point source pollutants are estimated to be } 1718 \text { tons SS/year, generated from } \\
\text { runoff over pavements } \\
\text { - Point source pollution mainly happen along Yongfeng River, resulting from combined } \\
\text { sewer overflow and illicit connections }\end{array}$ & $\begin{array}{l}\text { - The ratio of water bodies achieving quality } \\
\text { requirements: } 85 \% \\
\text { - Non-point source pollution reduction ratio: } 50 \% \text { for } \\
80 \% \text { of built area } \\
\text { - Water quality standard: Class IV or better }\end{array}$ \\
\hline Water resource & $\begin{array}{l}\text { - Pipe leakage ratio in Nanjing is above } 16 \% \\
\text { - There is almost no stormwater reuse practice in Qinhuai District }\end{array}$ & $\begin{array}{l}\text { - Stormwater reuse ratio: }>5 \% \\
\text { - Pipe leakage ratio: }<10 \%\end{array}$ \\
\hline Water culture & $\begin{array}{l}\text { Difficulties lie in water-related cultural heritage protection. Water culture has not been } \\
\text { incorporated into the urban fabric and inhabitants' daily life }\end{array}$ & $\begin{array}{l}\text { - Reshape historical spaces } \\
\text { - Incorporate waterfronts into urban landscape }\end{array}$ \\
\hline
\end{tabular}

five water topics of the current Sponge City approach are identified, as summarized in Table 2.

\section{Applying the Enhanced Version of Sponge City Planning Approach in Qinhuai District}

A brief overview of results, based on the key enhancements mentioned above, is as follows:

1. Elaborate the guiding principles based on the local conditions.

Based on site analysis using the Layers Approach, guiding principles were used to connect water and space given the local conditions in the area. Three key principles for Qinhuai were:

1. Prevent shifting; retain and store, rather than quick drainage.

Retention and detention are essential in delaying peak flow and controlling runoff volumes. Storage can lead to other cobenefits such as mitigation of non-point source pollution, groundwater recharge, drought mitigation, stormwater reuse, etc.

The required storage capacity for pluvial flood prevention was assessed to be $86 \mathrm{~mm}$ on average, based on the required 50-years return period, the available pumping capacity in the (sub) districts, 10-years climate forcing (precipitation and evaporation), and catchment properties as inputs. More details on these storage capacity calculations and the underlying StorageDischarge-Frequency (SDF) curves can be found in Supplementary Material SF. Storage requirements for each subzone are visualized in Figure 8. These storage depths are used as storage capacity targets in the planning of sponge measures.
2. Three Points Approach.

Introducing blue-green measures for creating storage capacity will deliver multi-functional land use and produce co-benefits concerning ecology, recreation, and urban heat island mitigation while providing storage, coping, and adaptive capacity as well as added value.

A long list of nature-based sponge measures is selected for four typical urban topologies (see Figure 9 and Supplementary Material SG). Figure 9 also includes the expected responsible authority in Nanjing for each of the adaptation measures and the bureaus that are possible (to be) involved in the planning, design, implementation, and maintenance of these facilities.

3. Logical priority of interventions.

As the long list of blue-green measures is large, a logical strategy is needed to prioritize different interventions. Given their potential sponge size and complexity of implementation, a logical hierarchy of spatial sponge interventions was made. Sponge retention was created in 1. Public green spaces; 2. Vacant lots and infrastructural spaces; 3. Residential green spaces; 4. Temporary sponges on small roads; 5. Green roofs (see Figure 10). Suggested interventions were prioritized accordingly.

2. Take a comprehensive water management approach.

It would have been preferable to first study the regional water system at the scale of the Qinhuai river basin before starting the Sponge City planning at the district scale. This could have answered the question on the acceptable capacity of the pumping stations that drain the subdistricts. However, limited data hinder such a basin-level water system analysis. This being unknown, it is assumed that the capacity of these stations should stay unchanged when assessing the required storage capacity in the sub-districts, as shown in Figure 8. 


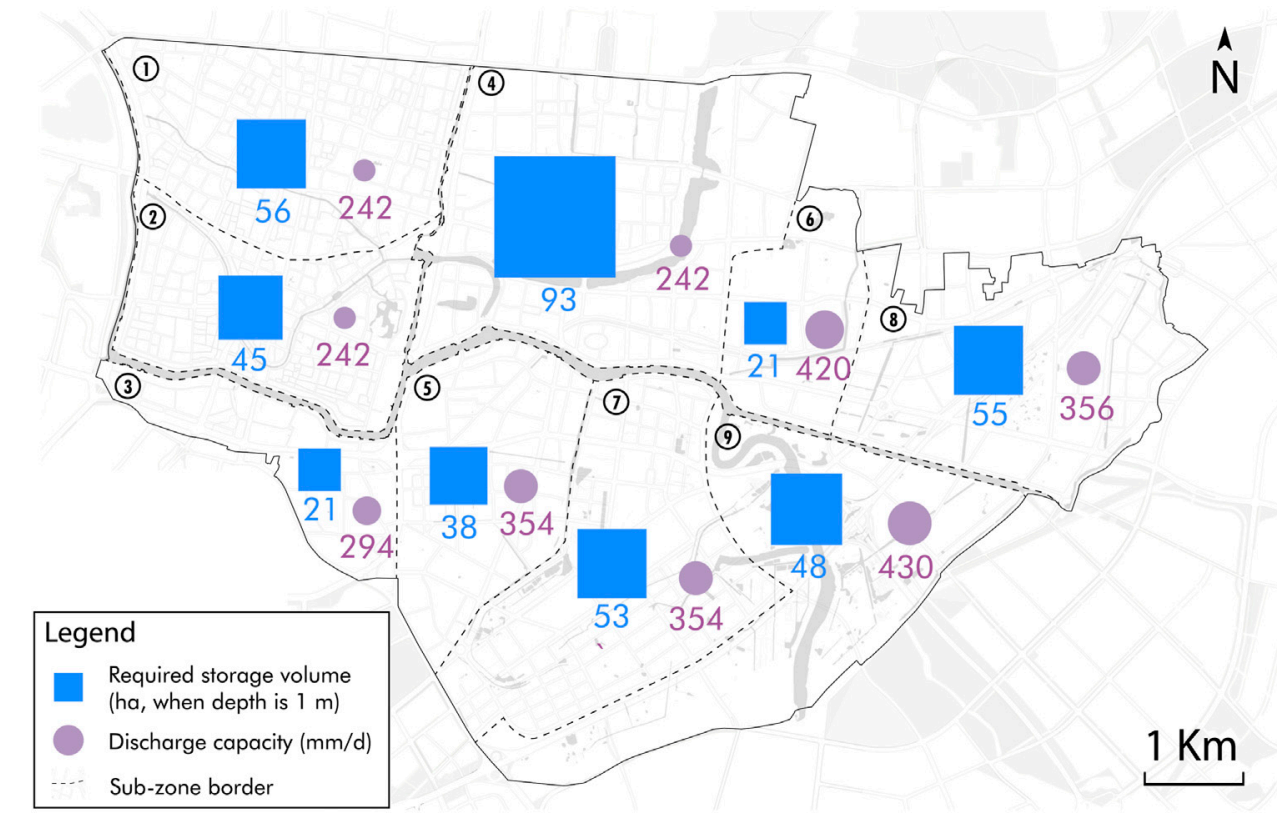

FIGURE 8 | The required storage capacities and discharge capacities for nine subzones of Qinhuai District.

The Urban Water Balance Model (Brolsma and Vergroesen, 2020) is employed to model the quantity of water components within Qinhuai subdistricts, including open water, unsaturated zone, groundwater (see Supplementary Material SF), etc. Modelling results are used to set the planning targets for pluvial flood prevention, drought mitigation, and groundwater management. The result shows that recharge of $0.72 \mathrm{~mm} / \mathrm{d}$ or $68 \mathrm{~mm}$ in total can help mitigate the most severe drought event.

Although water quality data of some canal sections give indications to planning priority, the available data are insufficient to simulate the overall water quality of the district.

3. Plan for added value.

Mapping the structure of potential Sponge City intervention with added values follows two steps: 1 . defining available spaces, including existing and planned green space, historical restrictions, existing small scale green space like roads/ neighbourhoods; 2 . defining preferred additional functions and services of interventions (either retention or detention). The resulting structure is shown in Figure 11, which consists of dotted, linear, patched, and nested sponges in public and private spaces aimed at strengthening the ecological, cultural, recreational, and social resilience of the district.

4. Co-design the plan, involving relevant experts and stakeholders.

The design of the final plan builds on established targets and requirements, the long list of potential interventions, the logical hierarchy of interventions, and the structure plan. Evidently, the planning of sponge solutions is not in the hands of a single bureau but requires coordination with experts from other bureaus as well as with representatives of the local population and businesses. Normally a collaborative design workshop with these representatives is to be held. The Covid-19 pandemic and lockdown, however, prevented such a meeting. Instead, local and international experts from the field of landscape architecture, urban water management, urban hydraulic engineering drafted a plan for pilot areas.

The Climate Resilient City Tool (van de Ven et al., 2016; McEvoy et al., 2018; McEvoy, 2019) was used to draft a plan for these pilot areas. One example area is shown in Figure 12. By adding a combination of bioswale (with drainage), infiltration boxes, water square, hollow roads, and rain gardens, this test area can reach $102 \mathrm{~mm}$ storage capacity (annual probability of exceedance less than 1/50) with co-benefits such as groundwater recharge $(0.71 \mathrm{~mm} / \mathrm{d}$ on average), runoff control and runoff pollution mitigation, etc. (see Figure 13). The measures in such an old city centre also improve biodiversity and, with aesthetic appeal, create opportunities for social interaction and recreational activities. Implementation enhances the attractiveness and liveability of the area every day, in addition to their hydrological functions.

\section{DISCUSSION}

\section{Evaluation of the Case Study}

The case study of Nanjing Qinhuai Sponge City planning demonstrates the feasibility and added value of applying the enhanced planning approach. Most of the proposed enhancements in aspects of planning content are successfully included in the analysis and results. From the perspective of the planning process, the case study demonstrates a comprehensive approach towards landscape design, water management, and spatial planning. Planning principles, site assessment, sponge measure selection, etc., were thoroughly discussed by the 


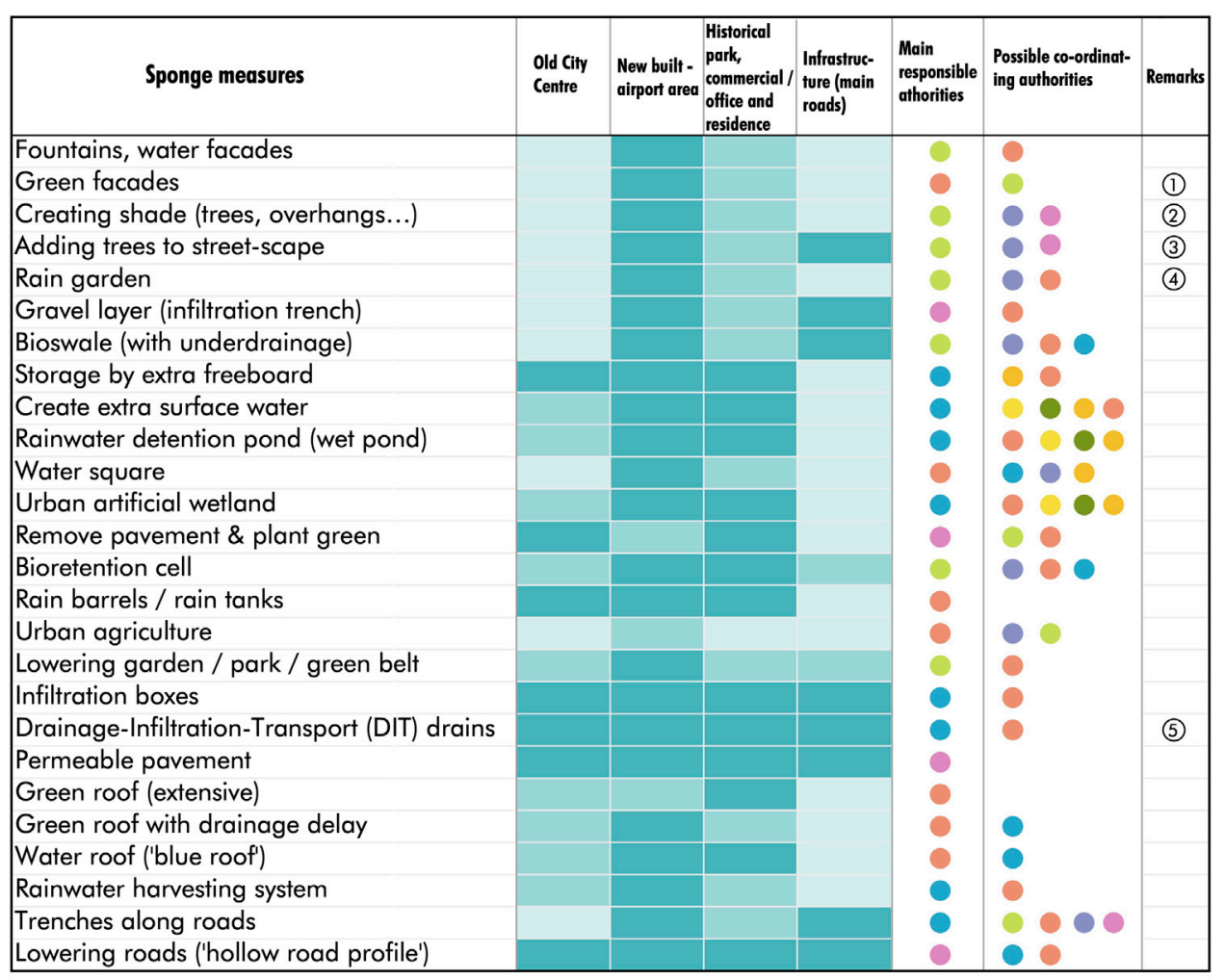

\begin{tabular}{|c|c|c|}
\hline \multicolumn{3}{|c|}{ Legend } \\
\hline & Less or not applicable & Housing and Urban \& Rural Development Bureau \\
\hline & Applicable in some situations & Environmental Protection Bureau \\
\hline & More widely applicable & Greening \& Landscaping Bureau \\
\hline & & Transportation Bureau \\
\hline (1) & for heat stress and landscaping & Water Affairs Bureau \\
\hline (2) & for heat stress and landscaping & Development \& Reform Comission \\
\hline (3) & for heat stress and landscaping & Urban Administration \& Comprehensive Law Enforcement Bureau \\
\hline (4) & tree-pit bioretention cells & Natural Resource \& Planning Bureau \\
\hline (5) & $\begin{array}{l}\text { in combination with subsurface (DIT) } \\
\text { drainage for groundwater level control }\end{array}$ & \\
\hline
\end{tabular}

FIGURE 9 | Sponge measure selections for four types of urban areas and responsible authorities for their design, implementation, and maintenance.

multi-disciplinary design team, during which local authorities were consulted to make adjustments.

The planning content also encountered obstacles. Calibration of the hydraulic models could not be performed due to the lack of data, which makes the assessment of flood-prone areas uncertain. On the other hand, the hydrologic water balance model could rely on data mainly available in the Qinhuai project; these include precipitation, land use and soil type. Hence, the results of this model are less uncertain. Moreover, the principle Never Shift Problems, resulting in a required storage capacity for pluvial flood protection, was not fully accepted by decision-makers; they considered the assessed capacity a recommended indicator rather than an obligatory one. As for the planning process, local inhabitants were not involved in the planning process. A co-design workshop could not be held due to Covid-19 restrictions. However, the final Qinhuai district Sponge City plan did highlight the importance of public involvement in future construction projects at smaller scales.

\section{Reflections on the Sponge City Approach}

The current Sponge City planning lacks fundamental building blocks to (re)design the water system in a comprehensive planning approach. (Li et al., 2017; Chan et al., 2018; Dai et al., 2018) which must be built on a hydrological analysis, consider land use and socio-economic situation, and contain a clear vision for the desired future situation. Without these essential frameworks, planners cannot deliver an integrative solution to complex issues of the local urban water management.

One crucial gap is that no quantified storage capacity is estimated for pluvial flood protection or drought mitigation. Sponge measure sizing is currently based on calculations of the VCRa, which is an ecological indicator that evoked debates 

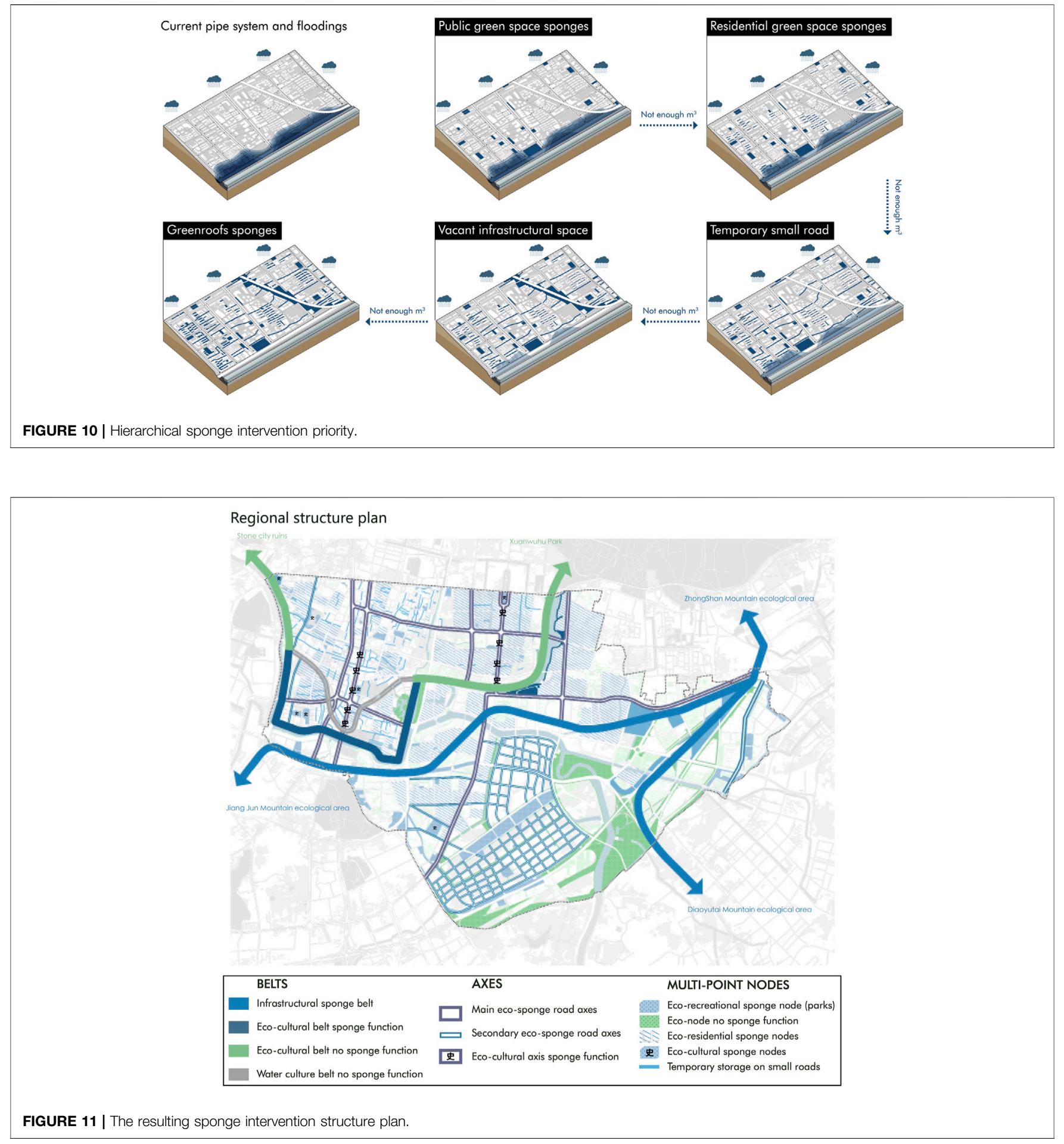

in academia (Wang et al., 2015; Che et al., 2016) and caused confusion to practitioners. Pluvial flood protection, however, requires more retention (sponge) capacity, which can be determined by assessing SDF-curves for the local situation.

Space is often very limited in compact Chinese cities. Yet, for cities with similar climate and urban features as Nanjing's Qinhuai District, the case study sets an example of finding sufficient space for water storage by applying the enhanced planning approach. For cities with different climatic and urban conditions, the focus and strategy in planning may shift to other aspects such as drought mitigation or water ecology rehabilitation, based on local conditions. Tuning the approach to the local situation will be required. More research is needed to find out what would be the best way to do this. 


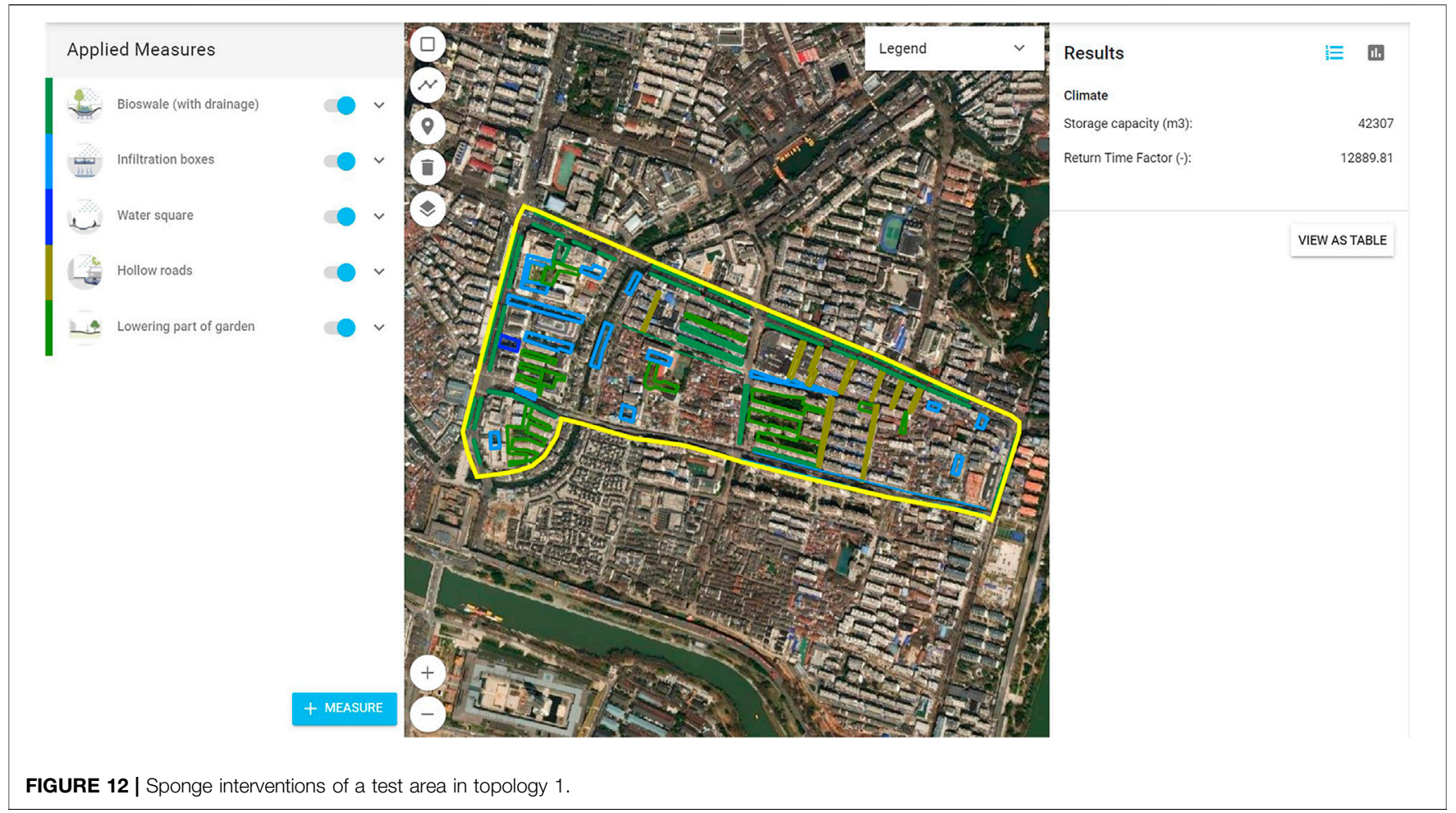

\begin{tabular}{|c|c|c|c|c|c|c|c|c|c|}
\hline \multicolumn{10}{|l|}{ Results } \\
\hline CLIMATE AND COSTS & CO BENEFITS & & & & & & & & \\
\hline Measure & Surface & $\begin{array}{l}\text { Storage } \\
\text { capacity (m3) }\end{array}$ & $\begin{array}{l}\text { Return Time } \\
\text { Factor }(-)\end{array}$ & $\begin{array}{l}\text { Groundwater } \\
\text { recharge } \\
(\mathrm{mm} / \mathrm{y})\end{array}$ & $\begin{array}{l}\text { Evapotranspira... } \\
(\mathrm{mm} / \mathrm{y})\end{array}$ & $\begin{array}{l}\text { Heat } \\
\text { reduction }\left({ }^{\circ} \mathrm{C}\right)\end{array}$ & $\begin{array}{l}\text { Cool areas } \\
(-)\end{array}$ & Construction & Maintenance \\
\hline $\begin{array}{l}\text { Bioswale (with } \\
\text { drainage) }\end{array}$ & 9537.51 & 3338 & 4.12 & 43 & 1 & 0.07 & 0 & 4291880 & 193135 \\
\hline Infiltration boxes & 16657.13 & 15477 & 68.82 & 156 & 0 & 0 & 0 & 94945649 & 30192716 \\
\hline Water square & 980.28 & 735 & 1.52 & 0 & 0 & 0.01 & 0 & 24262043 & 2620301 \\
\hline Hollow roads & 5690.5 & 1707 & 1.01 & 0 & 1 & 0 & 0 & 1024290 & 138279 \\
\hline $\begin{array}{l}\text { Lowering part of } \\
\text { garden }\end{array}$ & 23389.21 & 21050 & 25.16 & 61 & 3 & 0 & 0 & 3508382 & 210503 \\
\hline
\end{tabular}

Results

CLIMATE AND COSTS COBENEFITS

\begin{tabular}{lllll} 
Measure & Surface & $\begin{array}{l}\text { Pathogen } \\
\text { reduction (\%) }\end{array}$ & $\begin{array}{l}\text { Nutrient } \\
\text { reduction (\%) }\end{array}$ & 2 \\
$\begin{array}{l}\text { Bioswale (with drainage) } \\
\text { pollutants (\%) }\end{array}$ & 2 & 3 & 0 \\
\hline Infiltration boxes & 9537.51 & 4 & 0 & 0 \\
\hline Water square & 16657.13 & 0 & 0 & 0 \\
\hline Hollow roads & 980.28 & 0 & 1 & 3
\end{tabular}

FIGURE 13 | Estimated performance and co-benefits of sponge interventions of a test area in topology 1. 
As experienced during the implementation in the Qinhuai district, the enhanced approach encountered various challenges. Crucial ones include:

1. Data availability and accessibility.

Data plays an essential role in Sponge City planning. Data in this case study was not sufficient to support model calibration. The same problem appears in many other Chinese urban planning cases ( $\mathrm{Li}$ et al., 2017). Therefore, including data collection in the enhanced approach requires Chinese cities to enhance monitoring of their water systems, including water quality and groundwater. Sponge City planning also requires renovating current data sharing mechanisms, e.g., by establishing a standardized, freely-accessible, public data platform (Cai, 2016).

2. Innovation and collaboration.

In parallel to similar experiences in environment management (Lo, 2020), local authorities are less motivated to make innovative local Sponge City plans given the strict governance, especially on performance indicators, from the central government. This results in local planning agencies rigidly pursuing the fulfilment of the required performance indicators at the expense of curtailing local innovations. For example, the local requirement of downscaling the VCRa to each small piece of land hinders planning larger scaled public sponge measures, e.g., at sub-district level. Moreover, the limited communication between decision-makers, policy developers, and experts is a well-known barrier to planning novel solutions (Davoudi, 2006). The co-design process proposed in the enhanced approach would be a stepping-stone for stimulating local innovations by simply bringing relevant experts and stakeholders around the table and enabling them to exchange knowledge and expectations (van de Ven et al., 2016). The successful application of a customized Climate Resilient City Tool in Xiangtan City (van de Ven et al., 2020) demonstrates the value of such a tools-supported planning approach, though the effectiveness of its application to other Chinese cities remains to see.

3. Local actors' willingness and awareness.

As Thomas et al. (2018) concluded on policy transferability, "softer" transferable lessons (e.g., good actor relationships, information sharing, etc.) are much more difficult to transfer than 'harder' technical tools. Sharing your thoughts and ideas with others requires the willingness to do this. Another challenge is the local decision makers' attitude towards Never Shift Problems. Policy makers should realize the importance of local retention/detention capacity to avoid flooding problems in areas downstream. Knowledge transfer and bridge-building between experts, policy developers, and decisionmakers is essential for creating the awareness that this principle is at the heart of Sponge City planning.

\section{Limitations of the Methodological Approach}

Differences in local conditions result in other issues, other stakeholders, and, consequently, in slightly different planning processes. Auckland's WSD planning guidelines are not $100 \%$ representative of all WSD plans in New Zealand; and the Dutch also have other principles and use other tools in their water management planning. Likewise, Nanjing's Sponge City planning is not representative of all Sponge City planning in China. As a result, the enhanced approach as formulated and applied in this study for Qinhuai District is not the final solution. The approach needs customization to the local situation and can certainly be enriched and extended further by studying the success and failure of sustainable urban water planning in other cities in China and around the world. Moreover, insights in improving Sponge City planning, construction, and governance can be gained through collecting local stakeholders' experiences and feedback, in communities of practice, as well as by thoroughly monitoring and evaluating the effects of Sponge City interventions after implementation.

\section{CONCLUSION}

This paper presents the current Chinese Sponge City planning theory and local practice in Nanjing City. Through compare-andcontrast analysis between Nanjing's Sponge City planning approach and Auckland's Water Sensitive Design, as well as evaluation of Sponge City from the perspective of Dutch water management theories, gaps in the current policies were revealed, and potentials of enhancing planning approach were illuminated. An enhanced approach was proposed and applied in a case study of Nanjing's Qinhuai Sponge City planning project.

It can be concluded that the current performance-indicatororiented Sponge City planning approach is insufficiently integrative and comprehensive: elements are missing, both in terms of content and process. Missing elements include assessing the required water storage capacity for both pluvial flood protection and drought mitigation, groundwater management, the search for added values from blue-green nature-based solutions and involvement of local actors and experts from related disciplines in the planning process, etc.

The enhanced approach, facilitated by hydrological, hydraulic, and planning support tools, contributes to comprehensive and integrative planning, with active engagement of local stakeholders and experts from many different disciplines and City Bureaus. Results from the case study demonstrate the successful application of the enhanced approach for Qinhuai District, including quantifying the required storage capacity, interdisciplinary cooperation in setting principles and selecting sponge measures, formulating a logical hierarchy of interventions, and drafting a conceptual sponge city plan. The new approach received positive results and reactions, which makes us conclude that the adapted approach we proposed is indeed an enhanced version. Barriers appeared mainly on data availability and the awareness of the Never Shift Problems principle.

To maximize the economic, ecological, and social co-benefits of Sponge City interventions, future research is needed to relate the local urban system and the local water system. Moreover, implementation can benefit from co-creative planning workshops with experts and local stakeholders to elaborate the plan in more detail. These workshops could not take place earlier due to the COVID pandemic restrictions. Such participatory planning activities facilitate the knowledge exchange amongst various stakeholders and ensure the soundness and justness of Sponge City planning. Lastly, the results of this study can be used by other cities to improve their Sponge City planning approach and by China's central government to inspire improvements of the national Sponge City guidelines. It is recommended that the central government provides more support to encourage bottom-up mechanisms of policy 
implementation, including capacity building activities, financing, monitoring, data disclosure, and planning process evaluation studies.

\section{DATA AVAILABILITY STATEMENT}

The original contributions presented in the study are included in the article/Supplementary Material, further inquiries can be directed to the corresponding authors.

\section{AUTHOR CONTRIBUTIONS}

SC and FV contributed to conception and design of the study. LW collected and organised the data. SV contributed to the spatial analysis and the structural plan. SC wrote the first draft of the manuscript. All authors contributed to manuscript revision, read, and approved the submitted version.

\section{REFERENCES}

Adviesunit Resultaatgericht Beleid, Ministerie van Verkeer en Waterstaat (1997). Resultaatgericht beleid: advies bij beleidsontwikkeling, communicatie en samenwerking. Retrieved from https://puc.overheid.nl/ PUC/Handlers/DownloadDocument.ashx?identifier=PUC_102580_ 31 andversienummer $=1$.

Auckland Council (2016). The Auckland Code of Practice for Land Development and Subdivision. Retrieved from http://content.aucklanddesignmanual.co.nz/ regulations/codes-of-practice/stormwatercodeofpractice/details/Documents/ Auckland CoP Chapter 1 - Version $10 \_$Final v8.pdf.

Brolsma, R., and Vergroesen, T. (2020). Urban Water Balance Model. Retrieved from https://publicwiki.deltares.nl/display/AST/Urban+Water+balance+model.

Brown, R. R., Keath, N., and Wong, T. H. F. (2009). Urban Water Management in Cities: Historical, Current and Future Regimes. Water Sci. Tech. 59 (5), 847-855. doi:10.2166/wst.2009.029

Cai, L. (2016). Shiyong yu "haimianchengshi" de shuiwen shuili moxing gaishu [Introduction of Hydrological and Hydraulic Models for "Sponge City"]. Fengjing Yuanlin 02, 33-43.

Chan, F. K. S., Griffiths, J. A., Higgitt, D., Xu, S., Zhu, F., Tang, Y.-T., et al. (2018). "Sponge City" in China-A Breakthrough of Planning and Flood Risk Management in the Urban Context. Land Use Policy 76 (March), 772-778. doi:10.1016/j.landusepol.2018.03.005

Che, W., Zhang, K., Zhang, W., and Zhao, Y. (2016). Chuqi yushui yu jingliu zongliang kongzhi de guanxi ji qi yingyong fenxi [Analysis of the relationship between initial rainwater and total runoff control and its application]. Zhongguo jishui paishui 32 (6), 9-14.

Che, W., and Zhang, W. (2019). "Urban Stormwater Management and Sponge City Concept in China," in Urban Water Management for Future Cities: Technical and Institutional Aspects from Chinese and German Perspective. Editors S. Köster, M. Reese, and J. Zuo (Springer International Publishing), 3-11. doi:10.1007/978-3-030-01488-9_1

Chen, S. (2020). Sponge Design: A Study on Comprehensive Sponge City Design Approach. Delft: Delft University of Technology. http://resolver.tudelft.nl/uuid: a758663f-fb34-49bd-8cb7-03726938bc72.

Costa, S., Peters, R., Martins, R., Postmes, L., Keizer, J. J., and Roebeling, P. (2021). Effectiveness of Nature-Based Solutions on Pluvial Flood hazard Mitigation: The Case Study of the City of Eindhoven (the netherlands). Resources 10 (3), 24. doi:10.3390/resources 10030024

Cunningham, A., Colibaba, A., Hellberg, B., Silyn, G., Simcock, R., Speed, S., et al. (2017). Stormwater Management Devices In the Auckland Region.

Dai, Y., Jiao, S., Ding, G., and Shen, Y. (2018). Jin Shinian Haimianchengshi Jianshe Yanjiu Pingshu Yu Zhanwang [Review and prospect of Sponge City

\section{ACKNOWLEDGMENTS}

The research for this paper was supported by Delft University of Technology, Deltares, and China Europe Water Platform (CEWP). The Qinhuai case study could not be conducted without help from Nanjing Municipal Government, Qinhuai District Government, and Nanjing Hydraulic Research Institute (NHRI). Thanks to China Academy of Urban Planning and Design (CAUPD) for the collaboration in CEWP and for sharing their insights into Sponge City policy development, planning, and practice.

\section{SUPPLEMENTARY MATERIAL}

The Supplementary Material for this article can be found online at: https://www.frontiersin.org/articles/10.3389/fenvs.2021.748231/ full\#supplementary-material

Construction in Recent Ten Years]. Xiandai chengshi yanjiu 8, 77-87. doi:10.3969/j.issn.1009-6000.2018.08.011

Davoudi, S. (2006). Evidence-Based Planning. DisP - Plann. Rev. 42 (165), 14-24. doi:10.1080/02513625.2006.10556951

de Graaf, R., van de Giesen, N., and van de Ven, F. (2007). Alternative Water Management Options to Reduce Vulnerability for Climate Change in the Netherlands. Nat. Hazards 51 (3), 407-422. doi:10.1007/s11069-007-9184-4

De Hoog, M., Sijmons, D., and Verschuuren, S. (1998). Herontwerp Van Het Laagland, in Het Metropolitane Debat. Editor D. H. Frieling (Bussum: Uitgeverij THOTH), 74-87.

European Commission (2019). The European Green Deal. Eur. Comm. 53 (9), 24. doi:10.1017/CBO9781107415324.004

Fratini, C. F., Geldof, G. D., Kluck, J., and Mikkelsen, P. S. (2012). Three Points Approach (3PA) for Urban Flood Risk Management: A Tool to Support Climate Change Adaptation through Transdisciplinarity and Multifunctionality. Urban Water J. 9 (5), 317-331. doi:10.1080/1573062x.2012.668913

He, Y., and Xing, H. (2006). Woguo Chengshi Shuiwuran Xianzhuang Ji Qi Duice [The Urban Water Pollution Status Quo and Countermeasures in China]. Shuili Keji yu jingji 01, 44-45.

Healy, K., Carmody, M., and Conaghan, A. (2010). Operation and Maintenance of Stormwater Treatment Devices in the Auckland Region. Auckland: Auckland Regional Council. Available at: https://knowledgeauckland.org.nz/publications/ operation-and-maintenance-of-stormwater-treatment-devices-in-theauckland-region/.

Hooimeijer, F. L. (2014). The Making of Polder Cities: A fine Dutch Tradition. Heijningen: Jap Sam Books.

Hurlimann, A., and Wilson, E. (2018). Sustainable Urban Water Management under a Changing Climate: The Role of Spatial Planning. Water 10 (5), 546. doi:10.3390/w10050546

Kumar, P., Debele, S. E., Sahani, J., Aragão, L., Barisani, F., Basu, B., et al. (2020). Towards an Operationalisation of Nature-Based Solutions for Natural Hazards. Sci. Total Environ. 731, 138855. doi:10.1016/j.scitotenv.2020.138855

Lewis, M., James, J., Shaver, E., Blackbourn, S., Leahy, A., Seyb, R., et al. (2015). Water Sensitive Design For Stormwater (GD2015/004). Auckland: Auckland Council. Available at: http://content.aucklanddesignmanual.co.nz/projecttype/infrastructure/technical-guidance/Documents/GD04 WSD Guide.pdf.

Li, H., Ding, L., Ren, M., Li, C., and Wang, H. (2017). Sponge City Construction in China: A Survey of the Challenges and Opportunities. Water 9 (9), 594. doi:10.3390/w9090594

Li, X., Li, J., Fang, X., Gong, Y., and Wang, W. (2016). Case Studies of the Sponge City Program in China. World Environmental and Water Resources Congress, 2016, 295-308. doi:10.1061/9780784479858.031

Lin, B., Liao, Y., and Ding, H. (2019). Differentiation of "Volume Capture Ratio of Annual Rainfall. China Terminology 21 (5), 4. doi:10.3969/j.issn.1673-8578.2019.05.01 
Liu, H., and Han, D. (2014). Nanjing Laocheng Neihe Shuixi Xingtai Yanhua Jiedu [Interpretation of Inland River System Morphology Evolution in the Old City of Nanjing. Jianzhu yu wenhua 4, 12-19. doi:10.3969/j.issn.16724909.2014.04.002

Lo, K. (2020). Ecological Civilization, Authoritarian Environmentalism, and the Eco-Politics of Extractive Governance in China. Extractive Industries Soc. 7 (3), 1029-1035. doi:10.1016/j.exis.2020.06.017

Ma, Y., Jiang, Y., and Swallow, S. (2020). China's Sponge City Development for Urban Water Resilience and Sustainability: A Policy Discussion. Sci. Total Environ. 729, 139078. doi:10.1016/j.scitotenv.2020.139078

Mao, Y., Wu, H., Pei, H., He, P., and Liu, D. (2012). Jin 50a Nanjing xiaji jiangshui de qihou tezheng [Climate features of summer rainfall in Nanjing during recent 50a]. Qixiang kexue 32 (6), 646-652. doi:10.3969/2012jms.0047

McEvoy, S. (2019). Planning Support Tools in Urban Adaptation Practice. Delft: Delft University of Technology. doi:10.4233/uuid:48b7649c-5062-4c97-bba7970fc92d7bbf

McEvoy, S., van de Ven, F. H. M., Blind, M. W., and Slinger, J. H. (2018). Planning Support Tools and Their Effects in Participatory Urban Adaptation Workshops. J. Environ. Manage. 207, 319-333. doi:10.1016/j.jenvman.2017.10.041

McEvoy, S., van de Ven, F. H. M., Brolsma, R., and Slinger, J. H. (2019). Evaluating a Planning Support System's Use and Effects in Urban Adaptation: An Exploratory Case Study from Berlin, Germany. Sustainability 12 (1), 173. doi:10.3390/su12010173

MHURD 住建部 (2018). Haimian Chengshi Jianshe Pingjia Biaozhun [Evaluation Standards for Sponge City Construction, GB/T51345. Beijing: China Architecture \& Building Press. Retrieved from http://download.mohurd.gov. $\mathrm{cn} / \mathrm{bzgg} / \mathrm{gjbz} / \mathrm{GBT}$ 51345-2018海绵城市建设评价标准.pdf.

MHURD 住建部 (2015). Haimian Chengshi Jixiao Pingjia Yu Kaohe Zhibiao (Shixing) [Sponge City Construction Performance Evaluation and Evaluation Index (Trial)]. Retrieved from http://www.mohurd.gov.cn/wjfb/201507/ W020150715042911.doc.

MHURD 住建部 (2016). Zhufang chengxiang jianshe bu guanyu yinfa haimian chengshi zhuanxiang guihua bianzhi zanxing guiding de tongzhi [Notice of the Ministry of Housing and Urban-Rural Development on Printing and Distributing the Interim Provisions on the Preparation of the Special Planning for the Sponge City]. Retrieved from http://www.mohurd.gov.cn/ wjfb/201603/t20160317_226932.html.

MHURD 住建部 (2014). Zhufang chengxiang jianshe bu guanyu yinfa haimianchengshi jianshe jishu zhinan - - diyingxiang kaifa yushui xitong goujian (shixing) de tongzhi [Notice of the Ministry of Housing and UrbanRural Development on Issuing Technical Guidelines for Sponge City Construction-Low Impact Development Rainwater System Construction (Trial)]. Retrieved from http://www.mohurd.gov.cn/wjfb/201411/t20141102_ 219465.html.

Ministry of Infrastructure and Environment Affairs, \& Ministry of Economic (2009). National Water Plan (2016-2021). Retrieved from https://www. government.nl/documents/policy-notes/2015/12/14/national-water-plan2016-2021.

NPNRB 南京市规划局 (2018a). Guanyu Yinfa "Nanjing Shi Gongcheng Jianshe Xiangmu Lixiang Yongdi Guihua Xuke Jieduan Shenpi Shixiang Banli Guize" and "Nanjing Shi Gongcheng Jianshe Xiangmu Gongcheng Jianshe Xuke Jieduan Shenpi Shixiang Banli Guize" [Notice on Printing and Distributing the "Regulations for Approval in the Planning and Permit Phase of Land Use for Construction Projects in Nanjing" and "Rules for Approval in the Phase of Approval for Construction Permits for Engineering Construction Projects in Nanjing"] (NPNRB. Retrieved from http://ghj.nanjing.gov.cn/njsgtzyj/201811/ P020181204726302150849.pdf.

NPNRB 南京市规划局 (2018b). Nanjing Shi Haimian Chengshi Guihua Jianshe Zhinan [Guidelines for Planning and Construction of Sponge City in Nanjing] (Office of the Leading Group for the Construction of Nanjing Sponge City 南京 市海绵城市建设工作领导小组办公室. Retrieved from http://sjw.nanjing. gov.cn/tzgg/201807/P020181020788812936119.pdf.

OECD (2015). OECD Principles on Water Governance. Available at: https://www.oecd. org/cfe/regionaldevelopment/OECD-Principles-on-Water-Governance.pdf.

Qi, Y., Chan, F. K. S., Thorne, C., O’Donnell, E., Quagliolo, C., Comino, E., et al. (2020). Addressing Challenges of Urban Water Management in Chinese
Sponge Cities via Nature-Based Solutions. Water 12 (10), 1-24. doi:10.3390/ w12102788

Rijksplanologische Dienst (2001). Ruimtelijke Verkenningen 2000: Het Belang Van Een Goede Ondergrond. Ministerie van Volkshuisvesting, Ruimtelijke Ordening en Milieu. Netherlands: RPD The Hague.

State Council 国务院 (2015). Zhonggong zhongyang guowuyuan guanyu jiakuai tuijin shengtai wenming jianshe de yijian [Opinions of the Central Committee of the Communist Party of China and the State Council on Accelerating the Construction of Ecological Civilization. Retrieved from http://www.gov.cn/ gongbao/content/2015/content_2864050.htm.

Stead, D. (2014). Urban Planning, Water Management and Climate Change Strategies: Adaptation, Mitigation and Resilience Narratives in the Netherlands. Int. J. Sustain. Dev. World Ecol. 21 (1), 15-27. doi:10.1080/ 13504509.2013 .824928

Sun, Y., Chen, Z., Wu, G., Wu, Q., Zhang, F., Niu, Z., et al. (2016). Characteristics of Water Quality of Municipal Wastewater Treatment Plants in China: Implications for Resources Utilization and Management. J. Clean. Prod. 131, 1-9. doi:10.1016/j.jclepro.2016.05.068

Thomas, R., Pojani, D., Lenferink, S., Bertolini, L., Stead, D., and van der Krabben, E. (2018). Is Transit-Oriented Development (TOD) an Internationally Transferable Policy Concept. Reg. Stud. 52 (9), 1201-1213. doi:10.1080/ 00343404.2018.1428740

van de Ven, F. H. M., Brolsma, R., Hulsman, H., Chen, S., Zhang, W., Zhu, R., et al. (2020). Climate Risk and Vulnerability Assessment, and the Xiangtan Climate Resilient Toolbox. Available at: https://www.adb.org/sites/default/files/linkeddocuments/52230-001-sd-04.pdf.

van de Ven, F. H. M., Snep, R. P. H., Koole, S., Brolsma, R., van der Brugge, R., Spijker, J., et al. (2016). Adaptation Planning Support Toolbox: Measurable Performance Information Based Tools for Co-creation of Resilient, EcosystemBased Urban Plans with Urban Designers, Decision-Makers and Stakeholders. Environ. Sci. Pol. 66, 427-436. doi:10.1016/j.envsci.2016.06.010

Wang, F., Yan, Z., Huang, W., and Zhou, Q. (2012). Chengshi Yushui Neilao Chengyin Ji Duice [Causes and Countermeasures of Urban Water Logging]. Zhongguo jishui paishui 28 (12), 15-17. doi:10.3969/j.issn.10004602.2012.12.004

Wang, H., Ding, L., Cheng, X., and Li, N. (2015). Hydrologic Control Criteria Framework in the United States and its Referential Significance to China. 46, 1261-1271. doi:10.13243/j.cnki.slxb.20150670

Xia, J., Zhang, Y., Xiong, L., He, S., Wang, L., and Yu, Z. (2017). Opportunities and Challenges of the Sponge City Construction Related to Urban Water Issues in China. Sci. China Earth Sci. 60 (4), 652-658. doi:10.1007/s11430016-0111-8

Yu, K., Li, D., Yuan, H., Fu, W., Qiao, Q., and Wang, S. (2015). Haimian Chengshi" Lilun Yu Shijian ["Sponge City": Theory and Practice]. Chengshi guihua 39 (06), 26-36.

Conflict of Interest: Author SV was employed by the company LOLA Landscape Architects. Author WZ was employed by the company Ewaters. Author LW was employed by the company Achterboschzantman International.

The remaining authors declare that the research was conducted in the absence of any commercial or financial relationships that could be construed as a potential conflict of interest.

Publisher's Note: All claims expressed in this article are solely those of the authors and do not necessarily represent those of their affiliated organizations, or those of the publisher, the editors and the reviewers. Any product that may be evaluated in this article, or claim that may be made by its manufacturer, is not guaranteed or endorsed by the publisher.

Copyright $\odot 2021$ Chen, van de Ven, Zevenbergen, Verbeeck, Ye, Zhang and Wei. This is an open-access article distributed under the terms of the Creative Commons Attribution License (CC BY). The use, distribution or reproduction in other forums is permitted, provided the original author(s) and the copyright owner(s) are credited and that the original publication in this journal is cited, in accordance with accepted academic practice. No use, distribution or reproduction is permitted which does not comply with these terms. 